\title{
Occurrence of Anguillicola crassus (Nematoda: Dracunculoidea) in Japanese eels Anguilla japonica from a river and an aquaculture unit in SW Taiwan
}

\author{
M. Münderle ${ }^{1, *}$, H. Taraschewski ${ }^{1}$, B. Klar ${ }^{2}$, C. W. Chang ${ }^{3}$, J. C. Shiao ${ }^{3}$, \\ K. N. Shen ${ }^{3}$, J. T. He ${ }^{3}$, S. H. Lin ${ }^{3}$, W. N. Tzeng ${ }^{3}$ \\ ${ }^{1}$ Zoologisches Institut, Ökologie/Parasitologie and, ${ }^{2}$ Institute for Mathematical Stochastics, Universität Karlsruhe, \\ 76131 Karlsruhe, Germany \\ ${ }^{3}$ Institute of Fisheries Sciences, College of Life Science, National Taiwan University, Taipei, Taiwan 106, ROC
}

\begin{abstract}
The infection by swimbladder nematodes of the genus Anguillicola (Dracunculoidea: Anguillicolidae) was examined in 2 populations of the Japanese eel Anguilla japonica in SW Taiwan. Wild eels from the Kao-Ping river were compared with cultured eels from an adjacent aquaculture unit. Only the cosmopolitan species Anguillicola crassus was present. Among wild eels, prevalence of infection varied between 21 and $62 \%$, and mean intensity between 1.7 and 2.7 for adult worms. Similar intensity values (1.3 to 2.8 ) were recorded for the larvae. In cultured eels, prevalence as well as mean intensities were higher. In the cultured hosts, mean larval intensities exceeded those of adult worms 2 -fold, and maximum larval intensities were 4 - to 5 -fold higher than in eels from the river. In cultured eels, dead larvae were also more abundant than in wild eels. We conclude that infrapopulations of $A$. crassus in Japanese eels are regulated by the defense system of this host, intraspecific density-dependent regulation being less likely as the major regulatory mechanism. No influence of the parasite on eel condition was found in either wild or cultured eels, indicating a low or moderate pathogenic effect of $A$. crassus on this host. This study shows that $A$. crassus is moderately common in cultured and wild Japanese eels in Taiwan, where the parasite is endemic.
\end{abstract}

KEY WORDS: Anguillicola crassus · Anguilla japonica · Swimbladder · Taiwan · Aquaculture Resale or republication not permitted without written consent of the publisher

\section{INTRODUCTION}

Anguillicola crassus Kuwahara, Niimi \& Itagaki, 1974 , is an endemic swimbladder parasite of the Japanese eel Anguilla japonica in East Asia (Kuwahara et al. 1974, Nagasawa et al. 1994). The parasite has successfully spread to Europe, North Africa and North America, where it has attained high prevalence and intensities within populations of the European eel A. anguilla and the American eel A. rostrata, respectively (Neumann 1985, Taraschewski et al. 1987, Køie 1988, Moravec \& Taraschewski 1988, Moravec 1992, Johnson et al. 1995, Fries et al. 1996, Maamouri et al. 1999, Sures et al. 1999b, Kirk 2003). The parasite was obviously introduced to Europe with live-eel imports from Taiwan to the German harbor of Bremerhaven (see Koops \& Hartmann 1989, Køie 1991).
In Europe, this alien parasite has created interest among ichthyoparasitologists and individuals involved in fisheries and aquaculture because of its high pathogenicity in the economically important European eel, which had not coevolved with the parasite (Boon et al. 1990, Van Banning \& Haenen 1990, Molnár 1993, 1994, Hartmann 1989, Molnár et al. 1993, 1995, Würtz et al. 1996, 1998, Knopf et al. 1998, Kelly et al. 2000, Würtz \& Taraschewski 2000, Kirk 2003).

According to the available literature, the European and the Asian populations of Anguillicola crassus seem to differ in several aspects of their life-cycle and their host-parasite relations. In Asia as well as in Europe different copepods and ostracods are known to act as intermediate hosts (Hirose et al. 1976, De Charleroi et al. 1990, Kennedy \& Fitch 1990, Thomas 1993, Moravec \& Konecny 1994, Nagasawa et al. 1994, Ooi et 
al. 1997, Kirk et al. 2000a,b, Moravec et al. 2005). However, transmission via paratenic hosts has not been described from Asia, whereas in Europe various species of fishes as well as amphibians and even larvae of aquatic insects have been found to carry $L_{3}$ (and partly $\mathrm{L}_{4}$ ) -larvae in their viscera or their swimbladders (Haenen \& van Banning 1990, Thomas \& Ollevier 1992, Moravec \& Konecny 1994, Székely 1994, Moravec \& Škoríková 1998, Sures et al. 1999a). These differences might be due to the more intensive research activity related to A. crassus in Europe in comparison to Asia. However, parallel laboratory infections with A. japonica and $A$. anguilla have revealed a more severe host reaction directed against $A$. crassus in Japanese eels than in European eels (Nielsen \& Buchmann 1997, Nielsen 1999, Knopf \& Mahnke 2004).

The present study is the first report on Anguillicola crassus in wild and cultured populations of Japanese eels in Taiwan. Our aim was to study population structures of A. crassus in its Asian heartland and compare them with those described from Germany and Europe, where this invasive species has established a dense mesh of huge metapopulations over the last 20 yr. Furthermore, our investigation was also meant to have practical relevance. Eel farming hFas become a prosperous industry in Taiwan, China and other east and southeast Asian countries (Lee et al. 2003a, b). The aquaculture plants are run with A. japonica and other Asian or non-Asian eel species (Ooi et al. 1996, 1999, Shin \& Chen 2000, Chang et al. 2002). Unfortunately, these eel farms do not publish their experiences with A. crassus, and so the otherwise well-organized fishery management in Asia still depends on published data collected from Japanese eel farms more than 25 yr ago (Egusa 1979).

\section{MATERIALS AND METHODS}

Wild eels were collected from the Kao-Ping River in SW Taiwan from December 2000 to March 2003. The sampling locations and the methods of eel capture have been described in detail by Tzeng et al. (2002). Farm eels were purchased from 2 ponds of an aquaculture system at Bu-Dai in SW Taiwan in February and March 2003. In the years 2000 to 2002, live eels were transported to the laboratory, killed by decapitation, and deep-frozen until parasitological examination. In the year 2003, eels were investigated in fresh condition.

The length and weight of the eels were measured to the nearest $1.0 \mathrm{~mm}$ and $0.1 \mathrm{~g}$, respectively. The sex of each eel was determined according to external morphology and visual examination of the gonads. The developmental stage of the fish was classified as either a yellow or silver eel according to skin and fin coloration, eye diameter and gonad development (Pankhurst 1982, Han et al. 2003). The condition (c- or corpulence-factor) of the eels was calculated as described by Schäperclaus (1990).

The adult parasites were removed from the swimbladder lumen of the eels by forceps; their species, sex and number were recorded. The walls of the swimbladders were checked for larval stages $\left(\mathrm{L}_{3}\right.$ and $\left.\mathrm{L}_{4}\right)$ by squash preparation using 2 Perspex plates. In accordance with the results of Blanc et al. (1992), all larvae with a body length $>1.5 \mathrm{~mm}$ were considered Stage $\mathrm{L}_{4}$ larvae. The prevalence, mean intensity and abundance of the parasites in the eels were calculated as described by Bush et al. (1997). Additionally, we also counted encapsulated dead larvae and adults or remnants of both stages, but without determining the sex.

For taxonomic studies, adult worms were cleaned carefully with distilled water and then fixed and stored in $70 \%$ alcohol until morphometrical investigation. We measured the following features: length/width of body, length/width of oesophagus, length/width of buccal capsule and number of peribuccal teeth. Ratios of length and width of the body, oesophagus and buccal capsule were calculated.

For statistical analysis of the infection ( $p \leq 0.05)$ and condition ( $\mathrm{p} \leq 0.01)$ data, a Mann-Whitney $U$-test was employed. Spearmans correlation coefficient was used to determine the correlations between the different parameters (Sachs 1992). All results were checked for outliers according to the outlier test $\mathrm{n} \cdot \mathrm{SD}>4, \mathrm{p}<0.05$.

\section{RESULTS}

\section{Eel data}

Sex, developmental stage, body length, weight and condition of the investigated Japanese eels are summarized in Table 1. The sex ratios of the eels were skewed towards females in wild eels but towards males in cultured eels, similarly to results from previous studies eels in Taiwan (Tzeng et al. 1995, 2002).

The cultured eels had higher C-factors than the wild eels sampled in spring 2003, which could indicate that the availability of food or temperature are more favorable under culture conditions than in the river.

\section{Identification and measurement of Anguillicola crassus}

All adult nematodes collected from the lumen of the swimbladders of all wild and cultured Japanese eels were identified as Anguillicola crassus Kuwahara, Niimi \& Itagaki, 1974, using the key of Moravec \& Tara- 
Table 1. Anguilla japonica. Percentage of females and silver eels in samples, and mean $( \pm \mathrm{SD})$ weight, length and condition factor of all eels examined (including males). R: river, C: cultured eels

\begin{tabular}{|c|c|c|c|c|c|c|}
\hline Locality/ date & $\mathrm{n}$ & $\begin{array}{l}\text { Perce } \\
\text { Females }\end{array}$ & $\begin{array}{l}\text { tage } \\
\text { Silver }\end{array}$ & $\begin{array}{l}\text { Weight } \\
\text { (g) }\end{array}$ & $\begin{array}{l}\text { Lenght } \\
\text { (cm) }\end{array}$ & C-factor \\
\hline R/ Dec 2000 & 14 & 50 & 43 & $385.2 \pm 168.2$ & $62.0 \pm 6.3$ & $0.15 \pm 0.02$ \\
\hline R/ Mar 2001 & 20 & 100 & 10 & $289.4 \pm 125.5$ & $58.4 \pm 7.8$ & $0.14 \pm 0.01$ \\
\hline R/ Jun 2001 & 20 & 75 & 0 & $229.4 \pm 66.5$ & $52.0 \pm 4.3$ & $0.16 \pm 0.02$ \\
\hline R/ Sep 2001 & 21 & 86 & 0 & $178.0 \pm 46.1$ & $51.4 \pm 4.4$ & $0.13 \pm 0.01$ \\
\hline R/ Aug 2002 & 20 & 78 & 0 & $205.3 \pm 138.2$ & $49.8 \pm 9.0$ & $0.15 \pm 0.02$ \\
\hline R/ Mar 2003 & 73 & 82 & 0 & $136.5 \pm 176.1$ & $43.8 \pm 11.5$ & $0.12 \pm 0.02$ \\
\hline C/ Feb 2003 & 25 & 4 & 0 & $248.0 \pm 49.6$ & $53.9 \pm 3.0$ & $0.16 \pm 0.01$ \\
\hline C/ Mar 2003 & 46 & 15 & 0 & $237.3 \pm 26.7$ & $54.8 \pm 2.4$ & $0.14 \pm 0.02$ \\
\hline
\end{tabular}

Table 2. Anguillicola crassus. Morphometric features of parasites from wild $(\mathrm{n}=168)$ and cultured $(\mathrm{n}=71)$ Japanese eels Anguilla japonica. Data for all seasons combined. $0^{7}:$ male; o : female

\begin{tabular}{|c|c|c|c|c|c|}
\hline \multirow[t]{2}{*}{ Characteristic } & \multirow[t]{2}{*}{ Sex } & \multicolumn{2}{|c|}{ Culture $\left(0^{\prime}=7 ; \circ=8\right)$} & \multicolumn{2}{|c|}{ River $\left(0^{1}=71 ;\right.$ o $\left.=47\right)$} \\
\hline & & $\min .-\max$ & $\overline{\bar{x}} \pm \mathrm{SD}$ & $\min -\max$ & $\bar{x} \pm \mathrm{SD}$ \\
\hline \multirow[t]{2}{*}{ No. of teeth } & $0^{17}$ & $22-28$ & $25.4 \pm 2.4$ & $18-33$ & $24.1 \pm 3.0$ \\
\hline & ㅇ & $24-30$ & $27.1 \pm 2.1$ & $20-30$ & $23.7 \pm 2.1$ \\
\hline \multirow[t]{2}{*}{ Dry weight } & $0^{7}$ & $0.0-0.3$ & $0.1 \pm 0.1$ & $0.0-2.6$ & $0.4 \pm 0.5$ \\
\hline & \multicolumn{4}{|c|}{ Body } & $4.1 \pm 4.9$ \\
\hline \multirow[t]{2}{*}{ length (mm) } & $0^{17}$ & $5.83-9.01$ & $7.1 \pm 1.4$ & $2.29-23.21$ & $9.4 \pm 3.8$ \\
\hline & & $3.3-19.7$ & $9.0 \pm 5.9$ & $4.54-31.45$ & $16.6 \pm 7.7$ \\
\hline \multirow[t]{2}{*}{ width (mm) } & $0^{1}$ & $0.24-0.52$ & $0.3 \pm 0.1$ & $0.14-1.55$ & $0.6 \pm 0.3$ \\
\hline & 오 & $0.22-1.30$ & $0.6 \pm 0.4$ & $0.21-3.59$ & $1.5 \pm 0.9$ \\
\hline \multirow[t]{2}{*}{ length:width } & $\sigma^{\prime}$ & $17.2-25.0$ & $21.1 \pm 3.0$ & $9.3-36.1$ & $16.6 \pm 4.4$ \\
\hline & \multicolumn{5}{|c|}{ Oesophagus } \\
\hline \multirow[t]{2}{*}{ length $(\mu \mathrm{m})$} & $0^{1}$ & $495-653$ & $611.0 \pm 58.1$ & $361-871$ & $621.5 \pm 85.3$ \\
\hline & 운 & $540-921$ & $682.5 \pm 140.7$ & $554-1040$ & $781.6 \pm 118.1$ \\
\hline \multirow[t]{2}{*}{ width $(\mu \mathrm{m})$} & $0^{7}$ & $119-198$ & $160.5 \pm 26.6$ & $69-248$ & $167.9 \pm 42.6$ \\
\hline & ㅇ & $119-287$ & $177.6 \pm 61.7$ & $129-347$ & $218.2 \pm 54.2$ \\
\hline \multirow[t]{2}{*}{ length:width } & $0^{7}$ & $3.3-4.3$ & $3.9 \pm 0.4$ & $2.7-6.5$ & $3.9 \pm 0.8$ \\
\hline & 우 & $3.2-5.3$ & $4.0 \pm 0.7$ & $2.7-5.0$ & $3.7 \pm 0.5$ \\
\hline \multirow[t]{2}{*}{ length $(\mu \mathrm{m})$} & $0^{\prime \prime}$ & $18-22$ & $19.8 \pm 1.7$ & $13-22$ & $18.3 \pm 2.2$ \\
\hline & 우 & $14-24$ & $20.7 \pm 3.3$ & $15-24$ & $19.9 \pm 1.8$ \\
\hline \multirow[t]{2}{*}{ width $(\mu \mathrm{m})$} & $0^{+}$ & $46-60$ & $51.8 \pm 5.4$ & $38-61$ & $48.2 \pm 5.3$ \\
\hline & 우요 & $45-69$ & $60.9 \pm 7.7$ & $39-69$ & $53.1 \pm 5.6$ \\
\hline \multirow{2}{*}{ width:length } & $0^{7}$ & $2.1-3.2$ & $2.6 \pm 0.3$ & $2.2-3.3$ & $2.6 \pm 0.2$ \\
\hline & o & $2.8-3.3$ & $3.0 \pm 0.2$ & $2.3-3.2$ & $2.7 \pm 0.2$ \\
\hline
\end{tabular}

eels collected in early 2003 was significantly lower than in the cultured eels. The most striking differences were the mean larval intensities and especially the maximum larval number per eel (Table 3).

We classified 4 groups of eels harboring dead Anguillicola crassus: (1)

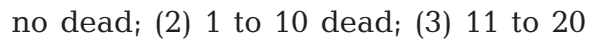
dead; (4) > 20 dead; (Fig. 1). The frequency distribution of dead Anguillicola crassus differed significantly between wild and cultured eels. We found dead A. crassus in $22 \%$ of the wild eels, whereas $56 \%$ of the cultured eels harbored at least 1 dead nematode (Fig. 1).

\section{Seasonal occurrence of Anguillicola crassus infection}

The prevalence of infection with Anguillicola crassus in wild eels was somewhat lower in the winter sample (December) than in the other seasons (Table 3), but the mean intensity of larval and adult $A$. crassus did not differ significantly among seasons except between September 2001 compared to December 2000 ( $p$ < 0.05). No comparison could be made for cultured eels since these were only available for 1 season.

\section{Frequency distribution of Anguillicola crassus infection}

The frequency distribution of adult and larval Anguillicola crassus per eel was calculated for wild and cultured schewski (1988). A. globiceps Yamaguti, 1935 was not found in any of the eels investigated. The morphological features of 133 specimens are summarized in Table 2.

\section{Prevalence and intensity of Anguillicola crassus infection}

Quantitative data on the swimbladder nematodes are presented in Table 3. Eels from the river had a lower prevalence $(\mathrm{P})$ of Anguillicola crassus $\left(\mathrm{P}_{\max }=\right.$ $62 \%)$ than cultured eels $\left(\mathrm{P}_{\max }=88 \%\right)$ The intensity of larval $(p<0.01)$ and adult worms $(p<0.05)$ in the wild eels, and approached a negative binomial distribution in the wild eel population, indicating a high degree of overdispersion (Fig. 2). In cultured eels, the extent of over dispersion was more pronounced, corresponding with the overall higher prevalence of infection in the cultured eels.

\section{Condition factor of eels}

We could not detect any significant difference in condition between uninfected and infected eels, either in the river or in the aquaculture population (Fig. 3). 
Table 3: Anguilla japonica infected with Anguillicola crassus. Prevalence (P), abundance (A) and mean intensity (MI) of parasites in wild (R) and of cultured (C) eels

\begin{tabular}{|c|c|c|c|c|c|c|c|}
\hline \multirow{3}{*}{$\begin{array}{l}\text { Locality/ } \\
\text { date }\end{array}$} & \multirow{3}{*}{$\begin{array}{l}\mathrm{P} \\
\%\end{array}$} & \multirow{3}{*}{$\begin{array}{c}\mathrm{A} \\
\bar{x} \pm \mathrm{SE}\end{array}$} & \multirow{2}{*}{\multicolumn{2}{|c|}{ (larvae) }} & \multicolumn{3}{|c|}{ Mean intensities } \\
\hline & & & & & $(\mathrm{ad}$ & & larvae + adults \\
\hline & & & $\bar{x} \pm \mathrm{SE}$ & $\max$. & $\bar{X} \pm \mathrm{SE}$ & $\max$ & SE max. \\
\hline $\mathrm{D}$ & 21 & 0 . & \pm 0 & 2 & .7 & 6 & $3.3 \pm 1.5 \quad 6$ \\
\hline 1 & 55 & & \pm & 2 & & 6 & 0.68 \\
\hline 1 & 60 & 1. & $1.3 \pm 0$ & 2 & .3 & 0 & $2 \pm 0.4 \quad 8$ \\
\hline 1 & 62 & $2 .($ & $2.8 \pm 1.0$ & 5 & .9 & 12 & $3.2 \pm 1.2 \quad 17$ \\
\hline 2 & 60 & $2.1 \pm$ & $2.7 \pm 1.0$ & 8 & 2.6 & 9 & $3.5 \pm 1.3 \quad 17$ \\
\hline R/ Mar 2003 & 51 & $1.2 \pm$ & $2.8 \pm 1.0$ & 12 & $1.7 \pm$ & 4 & $2.3 \pm 0.4 \quad 12$ \\
\hline C/ Feb 2003 & 88 & $6.7 \pm 2.9$ & $6.8 \pm 3.4$ & 64 & $2.9 \pm 0.6$ & 10 & $7.6 \pm 3.2 \quad 73$ \\
\hline C/ Mar 2003 & 65 & $4.4 \pm 1.3$ & $5.4 \pm 2.2$ & 42 & $2.9 \pm 0.6$ & 9 & $6.7 \pm 1.8 \quad 47$ \\
\hline \multicolumn{8}{|c|}{$\begin{array}{l}\text { an March 2003, } 1 \text { eel did not fit statistically ( } \mathrm{n} \cdot \operatorname{sigma}=8.44, \mathrm{p}=0 \text { ) and } \\
\text { was omitted from the table. We detected } 157 \text { larval stages and } 1 \text { adult } \\
\text { female in its swimbladder. It is likely that this fish had escaped from } \\
\text { an aquaculture farm }\end{array}$} \\
\hline
\end{tabular}

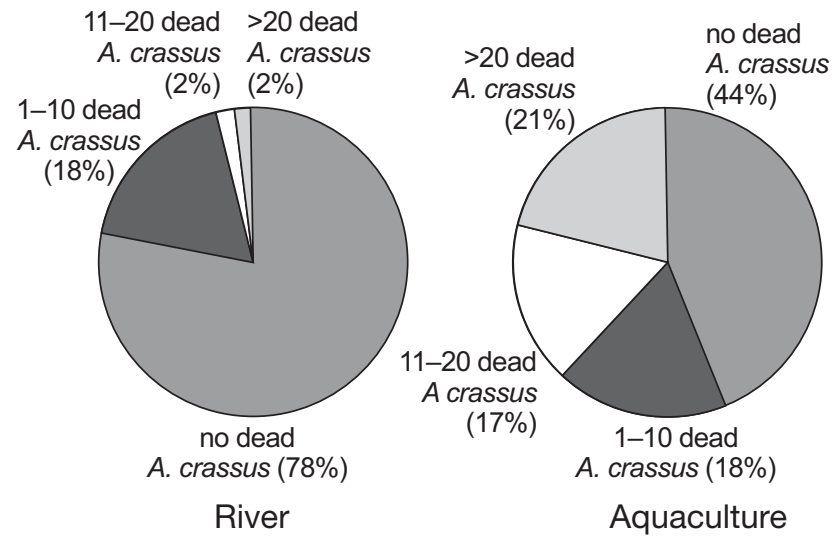

Fig. 1. Anguilla japonica infected with Anguillicola crassus. Frequency distribution of dead parasites (larvae and adults) found in wild ( $\mathrm{n}=168)$ and cultured $(\mathrm{n}=71)$ Japanese eels

\section{DISCUSSION}

The investigated populations of the Japanese eel Anguilla japonica in Taiwan harbored only 1 species of swimbladder nematode, Anguillicola crassus. This parasite has been recorded from East Asia within the central distributional range of $A$. japonica. The respective data from Japan, Korea and China have been reviewed by Nagasawa et al. (1994). Anguillicola globiceps, another swimbladder nematode occuring in Japanese eels, was not found in the present study. This latter parasite, originally described by Yamaguti (1935) from Japan, differs in several morphological features (oesophagus, buccal capsule, number of peribuccal teeth) from all other congeneric species (Moravec \& Taraschewski 1988), and is thus easily distinguishable from A. crassus. Nevertheless, in many reports from Japan, China and Taiwan, A. crassus and A. globiceps were not properly differentiated (see Kuo 1994, Nagasawa et al. 1994). Thus, due to lack of recent data, the distribution of these 2 species in East Asia is uncertain.

The pattern of seasonal occurrence of Anguillicola crassus described herein corresponds with reports for cultured Japanese eels in Japan (Egusa et al. 1969), with a lower prevalence in late winter and spring (February to April) than in summer (June to August). Decreased prevalence in winter was also noted in eels from Pusan, Korea (Kim et al. 1989). This could arise from, several factors such as lower availability of copepods during the cold or dry season in East Asia (November to April). During the rainy season, which begins in subtropical East Asia in May (Yen et al. 1990), the eels become more active (Tesch 1999).

The frequency of adult and larval nematodes approaches a negativly binominal distribution in wild

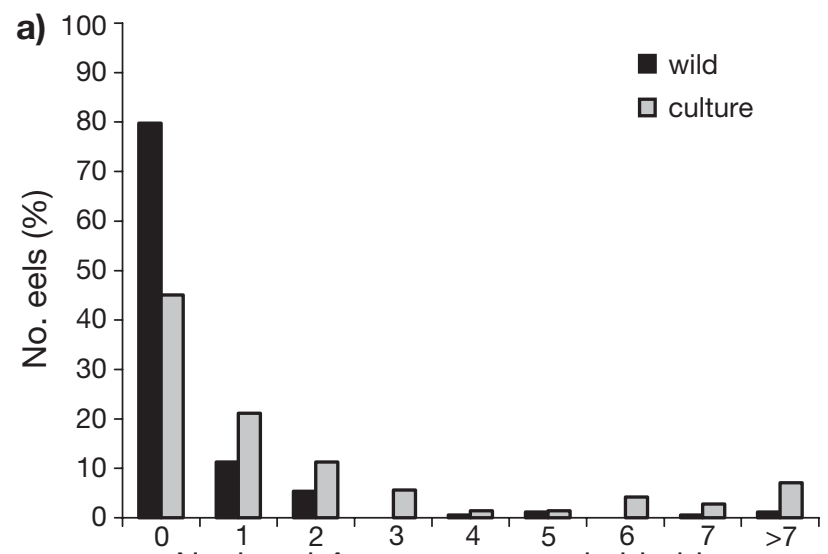

No. larval $A$. crassus per swimbladder

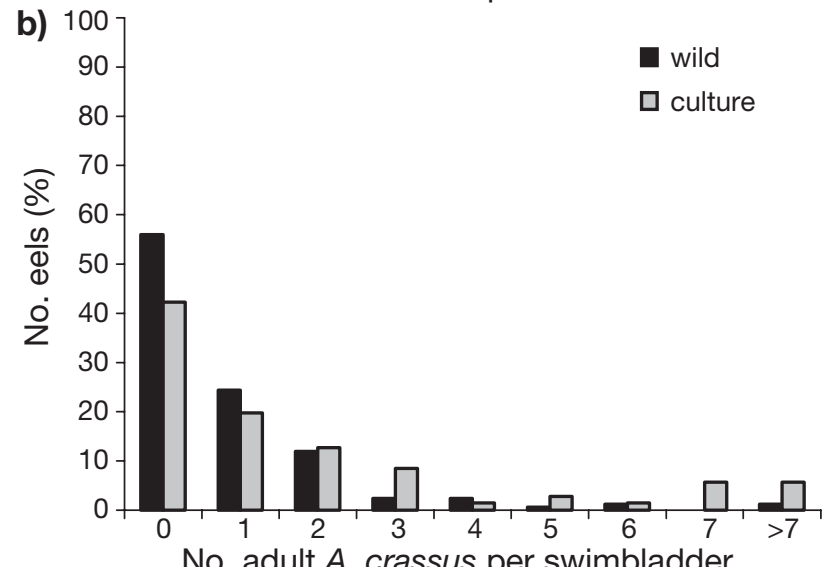

Fig. 2. Aguilla japonica infected with Anguillicola crassus. Observed frequency distribution of (a) larval and (b) adult parasites in wild $(n=168)$ and in cultured $(n=71)$ 

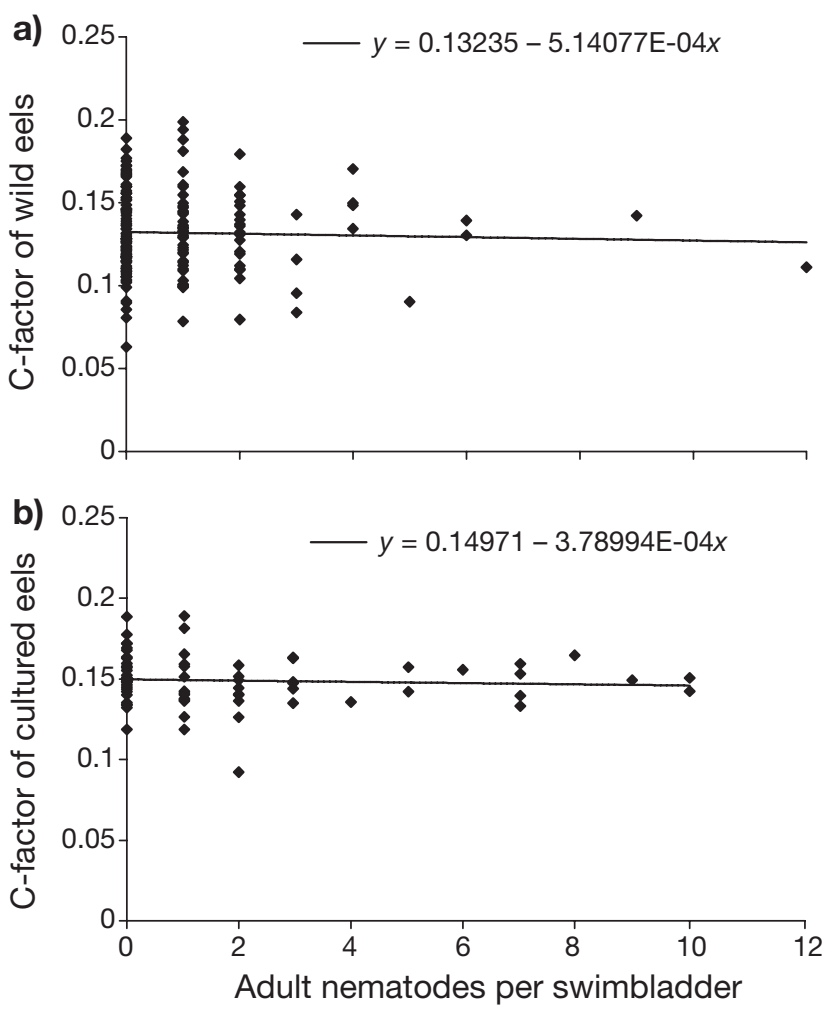

Fig. 3. Aguilla japonica infected with Anguillicola crassus. Condition factor (c-factor) of (a) wild $(\mathrm{n}=168)$ and (b) cultured (n = 71) Japanese eels as a function of infection intensity (adult parasites)

and cultured eels, revealing a high degree of overdispersion. This is characteristic of macroparasite infections in hosts (Anderson \& May 1978, Shaw \& Dobson 1995) and thus expected. Experimental infection of European eels with Anguillicola crassus revealed that a few hosts were responders in terms of antibody production, while others showed almost no reaction (Knopf et al. 2000a, b). Probably, Japanese eels (which have a stronger defense against $A$. crassus than European eels: Knopf \& Mahnke 2004) also differ markedly in their response. This heterogeneity might be the major causative mechanism behind the observed aggregation.

The results of our study, revealing prevalence rates of 21 to $88 \%$, contrast with data from Japan, where lower prevalences (10 to $40 \%$ ) of Anguillicola crassus have been described from wild and pond-reared Japanese eels (Moravec 1994). The river eels from Kao-Ping had a maximum prevalence of $62 \%$, which is within the range of data for European eels in Europe. Sures \& Streit (2001) reported $94 \%$ of eels examined from the river Rhine in Germany to be infected with $A$. crassus, whereas very low prevalences (6.7 to $8.9 \%$ ) were reported for the Butroe river in Spain (Gallastegi et al. 2002). These data show that infection rates of
Japanese as well as European eels can vary extremely between different habitats, obviously reflecting various ecological characteristics such as the availability of intermediate and/or paratenic hosts and the population density of the hosts. Nevertheless, the prevalence of 80 to $100 \%$ recorded for Europe (Kirk 2003) are unknown for East Asia (Moravec 1994, Nagasawa et al. 1994). The same applies to the intensity of infection (Kirk 2003): 30 yr after arrival of the parasites, eels in the river Rhine still harbor more than twice as many adult A. crassus (Sures \& Streit 2001) than Japanese eels in the Kao-Ping river.

Data on other host-parasite systems involving a native host and its indigenous Anguillicola species indicate lower abundances than in our study. From different populations of the Australian eel Anguilla australis in New Zealand Lefebvre et al. (2004) reported, very low prevalence $(<12 \%)$ and mean intensity infected with Anguillicola novaezelandiae (1 to 2 nematodes infected eel $^{-1}$ ). Taraschewski et al. (2005) detected similar low prevalence and intensity of $A$. papernai in Anguilla mossambica in South Africa. These observations suggest that $A$. crassus has very efficient modes of transmission and persistence, not only in recently adapted hosts such as the European eel, but also in its natural (East Asian) final and intermediate hosts. In Europe it quickly colonized the continent, whereas A. novaezelandiae introduced into a lake in Italy failed to spread, and finally disappeared (Paggi et al. 1982, Moravec et al. 1994).

Comparison of the 2 sampling areas in the present study revealed interesting differences in the host parasite interaction. The higher prevalence and intensity of infection in the cultured eels is probably related to the higher density of the final host (eel). In addition, intermediate hosts (copepods) seem to be sufficiently available in culture. Under aquaculture conditions, the high infection pressure is reflected by the 2-fold higher intensity of larvae compared to adults. Furthermore, the maximum larvae intensity was many times higher in cultured eels than in the eels from the river, where larvae and adults occurred at about the same intensity levels. However, mortality of the parasites in the cultured eels was considerably higher than in river eels. Thus, it appears that in the Japanese eel the infrapopulations of the parasite regulate themselves in a density dependent fashion or (more likely) become regulated by the immune system of this host (concomitant immunity).

In our field study on Anguilla japonica and its parasite Anguillicola crassus, high infection pressure was accompanied by high mortality among the parasites, obviously arising from the host's immune response to parasite-density pressure. Apparently, this host has evolved effective mechanisms for parasite recognition 
and defense during a long host-parasite coevolution. In the European eel, this has not been the case. Knopf \& Mahnke (2004) conducted comparative experimental infection of $A$. anguilla and A. japonica with A. crassus. In the Japanese eel, the recovery rates of the parasites were lower, their mortality higher and their individual weight lower than in the European eel. Knopf et al. $(2000 a, b)$ reported that the specific humoral immune response of European eels against $A$. crassus was characterized by a late onset and mainly directed against antigens in the body wall of adult nematodes. In comparison with European eels, Japanese eels showed an enhanced humoral immune response against antigens of A. crassus (Nielsen \& Buchmann 1997, Nielsen 1999), which might partly explain the differences in susceptibility between the 2 eel species.

We do not know whether the different survival rates of Anguillicola crassus in the 2 eel species is connected with the differential rise in antibodies, or whether the antibodies are just 'markers'. Nevertheless, the different host parasite relations, leading to different cellular alterations of the swimbladder-wall (Würtz \& Taraschewski 2000), are obviously connected with the different abundance and pathogenicity of the parasite in populations of the Japanese compared to the European eel.

The western part of Taiwan is still one of the fastest developing industrial zones of the world. However, it has no legislative restrictions on pollution (Chi 1994, Tsai et al. 2003). The consequences of rapid economic growth are nowadays ascertainable. The Kao-Ping River basin is not only the largest and most intensively used river in Taiwan, it is also heavily polluted (Kao et al. 2003). Livestock wastewater from hog farms, as well as municipal, domestic and industrial sewage represent the main sources of water pollution (Kao et al. 2003). Under these circumstances, it is surprising that sufficient suitable copepods are available to allow sufficient transmission of Anguillicola crassus to achieve the high prevalence (approx. 50\%) and intensity ( 2 adult worms per infected eel) reported here. Thus, our results support the hypothesis that $A$. crassus is a generalist which can persist under various environmental conditions.

Our findings show that Anguillicola crassus is still present in eel aquaculture in East Asia. In Bu-Dai aquaculture, no losses of eels associated with infection by $A$. crassus are known and the condition-factors calculated herein do not support high pathogenicity in the Japanese eel. Obviously the parasite is not a major problem in aquaculture systems based on the indigenous eel species Anguilla japonica. Thus far, all economic losses of cultured eels have occurred only when European (Egusa 1979) or American (Ooi et al. 1996) eels were involved as hosts. Accordingly A. crassus is not a major target in aquacultures with $A$. japonica. However, many countries in South and Southeast Asia, Oceania and Africa (South Africa, Moçambique, Madagascar, Réunion) are presently running pilot projects on establishing eel farms with local or imported eels ( $\mathrm{H}$. Taraschewski unpubl.). These projects should pay special attention to preventing the further spread of A. crassus.

Acknowledgements. The authors thank the National Science Council of the Rupublic of China for the financial support for specimen collection; 'Landesgraduiertenförderung' and 'Hochschulvereinigung' of the University Karlsruhe for supporting the first author's travel expenses from Germany to Taiwan; G. H. Chen, H. Y. Teng and H. Chu for help in field and laboratory work; Dr. T. Petney, Dr. C. H. Wang, Dr. C.L. Lin and Dr. C.W. Shin for valuable comments on the manuscript.

\section{LITERATURE CITED}

Anderson RM, May RM (1978) Regulation and stability of host-parasite population interactions. I. Regulatory processes. J Anim Ecol 47:219-247

Blanc G, Bonneau S, Biagianti S, Petter AJ (1992) Description of the larval stages of Anguillicola crassus (Nematoda, Dracunculoidea) using light and scanning electron microscopy. Aquat Living Resour 5:307-318

Boon JH, Cannaerts VMH, Augustijn H, Machiels MAM, De Charleroi D, Ollevier F (1990) The effect of different infection levels with infective larvae of Anguillicola crassus on haematological parameters of European eel (Anguilla anguilla). Aquaculture 87:243-253

Bush AO, Lafferty KD, Lotz JM, Shostak AW (1997) Parasitology meets ecology on its own terms: Margolis et al. revisited. J Parasitol 83:575-583

Chang PH, Pan YH, Wu CM, Kuo ST, Chung HY. (2002) Isolation and molecular characterization of herpesvirus from cultured European eels Anguilla anguilla in Taiwan. Dis Aquat Org 50:111-118

Chi CC (1994) Growth with pollution: unsustainable development in Taiwan and its consequences. Stud Comp Int Dev 29:23-47

De Charleroi D, Grisez L, Thomas K, Belpaire C, Ollevier F (1990) The life cycle of Anguillicola crassus. Dis Aquat Org 8:77-84

Egusa S (1979) Notes on the culture of the European eel (Anguilla anguilla) in Japanese eel-farming ponds. Rapp P-V Réun Cons Int Explor Mer 174:51-58

Egusa S, Kira K, Wakabayashi H (1969) On the occurrence of Anguillicola globiceps Yamaguti, a swimbladder roundworm, in pond cultured eels. Fish Pathol 4:52-58

Fries LT, Williams DJ, Johnson SK (1996) Occurrence of Anguillicola crassus, an exotic parasite swim bladder nematode of eels, in the southeastern United States. Trans Am Fish Soc 125:794-797

Gallastegi I, Rallo A, Mulcahy MF (2002) A report of Anguillicola crassus from Spain. Bull Eur Assoc Fish Pathol 22: 283-284

Haenen OLM, Van Banning P (1990) Detection of larvae of Anguillicola crassus (an eel swimbladder nematode) in freshwater fish species. Aquaculture 87:103-109

Han YS, Liao IC, Huang YS, He JT, Chang CW, Tzeng WN (2003) Synchronous changes of morphology and gonadal development of silvering Japanese eel Anguilla japonica. Aquaculture 219:783-796 
Hartmann F (1989) Investigations on the effectiveness of Levamisole as a medication against the eel parasite Anguillicola crassus (Nematoda). Dis Aquat Org 7:185-190

Hirose H, Sekino T, Egusa S (1976) Notes on the egg deposition, larval migration and intermediate host of the nematode Anguillicola crassa parasitic in the swimbladder of eels. Fish Pathol 11:27-31

Johnson SK, Loraine TF, Williams J, Huffman DG (1995) Presence of the parasitic swimbladder nematode, Anguillicola crassus, in Texas aquaculture. World Aquacult 26:35-36

Kao CM, Wu FC, Chen KF, Lin TF, Yen YE, Chiang PC (2003) Pollutant sources investigation and remedial strategies development for the Kaoping River Basin, Taiwan. Water Sci Technol 48:97-103

Kelly CE, Kennedy CR, Brown JA (2000) Physiological status of wild European eels (Anguilla anguilla) infected with the parasitic nematode, Anguillicola crassus. Parasitology 120:195-202

Kennedy CR, Fitch DJ (1990) Colonization, larval survival and epidemiology of the nematode Anguillicola crassus, parasitic in the eel, Anguilla anguilla, in Britain. J Fish Biol 36: 117-131

Kim YG, Kim EB, Kim JY, Chun SK (1989) Studies on a nematode. Anguillicola crassa parasitic in the air bladder of the eel. J Fish Pathol 2:1-18

Kirk RS (2003) The impact of Anguillicola crassus on European eels. Fish Manag Ecol 10:385-394

Kirk RS, Kennedy CR, Lewis JW (2000a) Effect of salinity on hatching, survival and infectivity of Anguillicola crassus (Nematoda: Dracunculoidea) larvae. Dis Aquat Org 40: 211-218

Kirk RS, Lewis JW, Kennedy CR (2000b) Survival and transmission of Anguillicola crassus Kuwahara, Niimi \& Itagaki, 1974 (Nematoda) in seawater eels. Parasitology 120: 289-295

Knopf K, Mahnke M (2004) Differences in susceptibility of the European eel (Anguilla anguilla) and the Japanese eel (Anguilla japonica) to the swim-bladder nematode Anguillicola crassus. Parasitology 129:491-496

Knopf K, Würtz J, Sures B, Taraschewski H (1998) Impact of low water temperature on the development of Anguillicola crassus in the final host Anguilla anguilla. Dis Aquat Org 33:143-149

Knopf K, Naser K, van der Heijden MHT, Taraschewski H (2000a) Hummoral immune response of European eel Anguilla anguilla experimentally infected with Anguillicola crassus. Dis Aquat Org 42:61-69

Knopf K, Naser K, van der Heijden MHT, Taraschewski H (2000a) Evaluation of an ELISA and immunoblotting for studying the humoral immune response in Anguillicola crassus infected European eel Anguilla anguilla. Dis Aquat Org 43:39-48

Koops H, Hartmann F (1989) Anguillicola infestations in Germany and German eel imports. J Appl Ichthyol 1:41-45

Køie M (1988) Parasites in eel Anguilla anguilla (L.), from eutrophic Lake Esrum (Denmark). Acta Parasitol Pol 33: 89-100

Køie M (1991) Swimbladder nematodes (Anguillicola spp.) and gill monogeneans (Pseudodactylogyrus spp.) parasitic on the European eel (Anguilla anguilla). J Cons Int Explor Mer 47:391-398

Kuo H (1994) Culture eel in perspective. Fisheries Publishing Taipei

Kuwahara A, Niimi A, Itagaki H (1974) Studies on a nematode parasitic in the air bladder of the eel. I. Description of Anguillicola crassa n. sp. (Philometridea, Anguillicolidae). Jpn J Parasitol 23:275-279
Lee WC, Chen YH, Lee YC, Liao IC (2003a) The competitiveness of the aquaculture in Taiwan, Japan and China. Aquaculture 221:115-124

Lee WC, Chen YH, Lee YC, Liao IC (2003b) Impact of successful larval rearing on the competitiveness of the eel aquaculture in Taiwan, Japan, and China. J Fish Soc Taiwan 30:43-53

Lefebvre F, Schuster T, Münderle M, Hine M, Poulin R (2004) Anguillicolosis in the short-finned eel Anguilla australis: epidemiology and pathogenicity. NZ J Mar Freshw Res 38: 577-583

Maamouri F, Gargouri L, Ould Daddah M, Bouix G (1999) Occurrence of Anguillicola crassus (Nematoda, Anguillicolidae) in the Ichkeul lake (Northern Tunisia). Bull Eur Assoc Fish Pathol 19:17-19

Molnár K (1993) Effect of decreased oxygen content on eel (Anguilla anguilla) infected by Anguillicola crassus (Nematoda, Dracunculoidea). Acta Vet Hung 41:349-360

Molnár K (1994) Formation of parasitic nodules in the swimmbladder and intestinal walls of the eel Anguilla anguilla due to infections with larval stages of Anguillicola crassus. Dis Aquat Org 20:163-170

Molnár K, Baska F, Csaba G, Glávits R, Székely C (1993) Pathological and histopathological studies of the swimbladder of eels Anguilla anguilla infected by Anguillicola crassus (Nematoda: Dracunculoidea). Dis Aquat Org 15: 41-50

Molnár K, Szakolczai J, Vetési F (1995) Histological changes in the swimbladder wall of eels due to abnormal location of adult and second stage larvae of Anguillicola crassus. Acta Vet Hung 43:125-137

Moravec F (1992) Spreading of the nematode Anguillicola crassus (Dracunculoidea) among eel populations in Europe. Folia Parasitol (Ceske Budejovice) 39:247-248

Moravec F (1994) Parasitic nematodes of freshwater fishes of Europe. Academia, Praha

Moravec F, Konecny R (1994) Some new data on the intermediate and paratenic hosts of the nematode Anguillicola crassus Kuwahara, Niimi \& Itakagi 1974 (Dracunculoidea), a swimbladder parasite of eels. Folia Parasitol (Ceske Budejovice) 41:65-70

Moravec F, Škoríková B (1998) Amphibians and larvae of aquatic insects as new paratenic hosts of Anguillicola crassus (Nematoda: Dracunculoidea), a swimbladder parasite of eels. Dis Aquat Org 34:217-222

Moravec F, Taraschewski H (1988) Revision of the genus Anguillicola Yamaguti, 1935 (Nematoda: Anguillicolidae) of the swimbladder of eels, including descriptions of two new species, Anguillicola novaezelandiaesp. n. and Anguillicola papernai sp. n. Folia Parasitol (Ceske Budejovice) 35:125-156

Moravec F, Dicave D, Orecchia P, Paggi L (1994) Experimental observations on the development of Anguillicola crassus (Nematoda, Dracunculoidea) in its definitive host, Anguilla anguilla (Pisces). Folia Parasitol (Ceske Budejovice) 41:138-148

Moravec F, Nagasawa K, Miyakawa M (2005) First record of ostracods as natural intermediate hosts of Anguillicola crassus, a pathogenic swimbladder parasite of eels Anguilla spp. Dis Aquat Org 66:171-173

Nagasawa K, Kim YG, Hirose H (1994) Anguillicola crassus and Anguillicola globiceps (Nematoda: Dracunculoidea) parasitic in the swimbladder of eels (Anguilla japonica and Anguilla anguilla) in East Asia: a review. Folia Parasitol (Ceske Budejovice) 41:127-137

Neumann W (1985) Schwimmblasenparasit Anguillicola bei Aalen. Fischer Teichwirt 11:322

Nielsen ME (1999) An enhanced humoral immune response 
against the swimbladder nematode, Anguilla crassus, in the Japanese eel, Anguilla japonica, compared with the European eel, Anguilla anguilla. J Helminthol 73: 227-232

Nielsen ME, Buchmann K (1997) Gluathione-s-transferase is an important antigen in the eel nematode Anguillicola crassus. J Helminthol 71:319-324

Ooi HK, Wang WS, Chang HY, Wu CH, Lin CC, Hsieh MT (1996) An epizootic of anguillicolosis in cultured American eel, Anguilla rostrata, in Taiwan. J Aquat Anim Health 8: 163-166

Ooi HK, Lin CC, Chen MC, Wang WS (1997) Eucyclops euacanthus (Copepoda: Cyclopidae) is an intermediate host of Anguillicola crassus (Nematoda: Dracunculoidea) in Taiwan. Taiwan J Vet Med Anim Husb 67:135-138

Ooi HK, Wang WS, Tu CY, Chang HY, Chen CI (1999) Natural mass infection by heterophyid metacercariae in aquacultured Japanese eel in Taiwan. Dis Aquat Org 35:31-6

Paggi L, Orecchia P, Minervini R, Mattiucci S (1982) Sulla comparsa di Anguillicola australiensis Johnston \& Mawson, 1940 (Dracuncoloidea: Anguillicolidae) in Anguilla anguilla del lago di Bracciano. Parassitologia 24:139-143

Pankhurst NW (1982) Relation of visual changes to the onset of sexual maturation in the European eel Anguilla anguilla (L.). J Fish Biol 21:127-140

Sachs L (1992) Angewandte Statistik, 7. Aufl. SpringerVerlag, Berlin

Schäperclaus W (1990) Fischkrankheiten. Akademie-Verlag, Berlin

Shaw DJ, Dobson AP (1995) Patterns of macroparasite abundance and aggregation in wildlife populations: a quantitative review. Parasitology 111:111-133

Shin JW, Chen CC (2000) Merthiolate-iodine-formalin stain method for diagnosis of cultured American eel anguillicolosis in Taiwan. J Fish Soc Taiwan 27:129-138

Sures B, Streit B (2001) Eel parasite diversity and intermediate host abundance in the River Rhine, Germany. Parasitology 123:185-191

Sures B, Knopf K, Taraschewski H (1999a) Development of Anguillicola crassus (Dracunculoidea, Anguillicolidae) in experimentally infected Balearic congers Ariosoma balearicum (Anguilloidea, Congridae). Dis Aquat Org 39: $75-78$

Sures B, Knopf K, Würtz J, Hirt J (1999b) Richness and diversity of parasite communities in European eels Anguilla anguilla of the River Rhine, Germany, with special reference to helminth parasites. Parasitology 119:323-330

Székely C (1994) Paratenic hosts for the parasitic nematode Anguillicola crassus in Lake Balaton, Hungary. Dis Aquat Org 18:11-20

Taraschewski H (2006) Hosts and parasites as aliens. J Helminthol 80:99-128

Taraschewski H, Moravec F, Lamah T, Anders K (1987)

Editorial responsibility: Wolfgang Körting,

Hannover, Germany
Distribution and morphology of two helminths recently introduced into European eel populations: Anguillicola crassus (Nematoda, Dracunculoidea) and Paratenuisentis ambiguus (Acanthocephala, Tenuisentidae). Dis Aquat Org 3:167-176

Taraschewski H, Boomker J, Knopf K, Moravec F (2005) Studies on the morphology and ecology of Anguillicola papernai (Nematoda: (Anguillicolidae) parasitizing the swimbladder of African longfin eel, Anguilla mossambica, and on the helminth community in this eel. Dis Aquat Org 62: 185-195

Tesch FW (1999) Der Aal. Paul Parey, Hamburg

Thomas K (1993) The life cycle of the eel parasite Anguillicola crassus (Nematoda, Dracunculoidea). Dissertation, Universität Leuven

Thomas K, Ollevier F (1992) Paratenic hosts of the swimbladder nematode Anguillicola crassus. Dis Aquat Org 13: 165-174

Tsai LJ, Ho ST, Yu KC (2003) Correlations of extractable heavy metals with organic matters in contaminated river sediments. Water Sci Technol 47:101-107

Tzeng WN, Cheng PW, Lin FY (1995) Relative abundance, sex ratio and population structure of the Japanese eel Anguilla japonica in the Tanshui River system of northern Taiwan. J Fish Biol 46:183-201

Tzeng WN, Han YS, He JT (2002) The sex ratios and growth strategies of wild and captive Japanese eels Anguilla japonica. In: Small B, MacKinlay D (eds) Developments in understanding fish growth. International Congress on the Biology of Fish. University of British Columbia, Vancouver, p 25-42

Van Banning P, Haenen OLM (1990) Effects of the swimmbladder nematode Anguillicola crassus in wild and farmed eel, Anguilla anguilla. In: Perkins FO, Cheng TC (eds) Pathology in marine science, Academic Press, New York, p 317-330

Würtz J, Taraschewski H (2000) Histopathological changes in the swimbladder wall of the European eel Anguilla anguilla due to infection with Anguillicola crassus. Dis Aquat Org 39:121-134

Würtz J, Taraschewski H, Pelster B (1996) Changes in gas composition in the swimbladder of the European eel (Anguilla anguilla) infected with Anguillicola crassus (Nematoda). Parasitology 112:233-238

Würtz J, Knopf K, Taraschewski H (1998) Distribution and prevalence of Anguillicola crassus (Nematoda) in eels Anguilla anguilla of the rivers Rhine and Naab, Germany. Dis Aquat Org 32:137-143

Yen CM, Chen ER, Cheng CW (1990) A survey of Ampullarium canaliculatus for natural infection of Angiostrongylus cantonensis in south Taiwan. J Trop Med Hyg 93:347-50

Yamaguti S (1935) Studies on the helminth fauna of Japan. Pt 9. Nematodes of fishes I. Jpn J Zool 6:337-386

Submitted: July 26, 2005; Accepted: January 30, 2006

Proofs received from author(s): July 15, 2006 